\title{
CORRIGENDUM
}

\section{Reduced-intensity conditioning regimen with in vivo T-cell depletion for patients with haematological malignancies: results using unrelated and sibling donors}

L Castagna, R Crocchiolo, S Furst, J El-cheikh, B Esterni, A Granata, A Stoppa, R Boubdallah, D Coso, N Vey, A Charbonnier, C Lemarie, C Faucher, C Chabannon and D Blaise

Bone Marrow Transplantation (2014) 49, 1248; doi:10.1038/bmt.2014.191

Correction to: Bone Marrow Transplantation (2014) 49, 1246-1247; doi:10.1038/bmt.2014.138; published online 7 July 2014

Since the publication of this article, it has been noted that the names of J El-cheikh and A Charbonnier were incorrect. This has now been rectified and the corrected article appears in this issue.

The authors apologize for any inconvenience this may have caused. 